\title{
Symulacja parametrów pracy podziemnego magazynu gazu w kontekście typu i szczelności podziemnej struktury magazynowej
}

\author{
Petr Bujok ${ }^{1}$ (D), Markéta Horáková ${ }^{2}$, Martin Klempa $^{1}$ (D), \\ Antonín Kunz ${ }^{1}$ D , Matěj Kř́stek ${ }^{1}$, Robert Rado ${ }^{3}$ (D), Milan Vašek ${ }^{2}$ \\ 1 VSB-TUO Ostrava, Faculty of Mining and Geology, Republika Czeska \\ 2 MND a.s Hodonín, Republika Czeska \\ 3 AGH Akademia Górniczo-Hutnicza, Wydział Wiertnictwa, Nafty i Gazu, Kraków
}

\begin{abstract}
Streszczenie: Do zapewnienia regularnych dostaw gazu ziemnego do systemu na wypadek wahań w jego popycie i podaży wykorzystuje się jego magazynowanie. Głównym zadaniem magazynów jest zapewnienie stabilności zaopatrzenia w gaz przez regulację operacyjną dostaw do systemów dystrybucji. Funkcjonowanie operacyjne magazynów gazu (PMG) zależy od typu i gazoszczelności struktur geologicznych, w których są zlokalizowane, infrastruktury technicznej magazynu oraz parametrów operacyjnych jego eksploatacji. Gazoszczelność zbiorników magazynowych jest jednym z podstawowych czynników wpływających na koszty operacyjne magazynowania gazu. W artykule przedstawiono modelownie parametrów konwersji i eksploatacyjnych dwóch różnych typów zbiorników magazynujących oraz ocenę pierwotnej gazoszczelności magazynów PMG Uhřice (MND Gas Storage a.s., Republika Czeska) i PMG Hähnlein (MND Gas Storage Germany GmbH, Niemcy). Monitorowanie i kontrolę bilansu ilości gazu w PMG przeprowadzono za pomocą krzywych $p / z$ oraz przy użyciu modelowania matematycznego.
\end{abstract}

Słowa kluczowe: podziemne magazyny gazu, gazoszczelność magazynów gazu, bezpieczeństwo magazynowania gazu, parametry operacyjne

\section{UNDERGROUND GAS STORAGE OPERATING PARAMETERS SIMULATION IN THE CONTEXT OF THE TYPE AND GAS TIGHTNESS OF GEOLOGICAL STRUCTURES}

\begin{abstract}
Gas storages are used to secure a regular supply of natural gas to the system in the case of fluctuations in the demand and supply. These storage facilities are to ensure the stability of gas supply through operational regulation of deliveries to the distribution systems. The operational functioning of gas storage facilities (UGS) depends on the type and gas tightness of the geological structures in which they are located, the technical infrastructure used in the operation of the storage facility, and the operational parameters of its operation. The gas tightness of collector storage tanks is one of the main factors affecting the operating costs of gas storage. The operating parameters for two different types of collector reservoirs and evaluation of primary gas tightness for the storage facilities UGS Uhřice (MND Gas Storage a.s., Czech Republic) and UGS Hähnlein (MND Gas Storage Germany GmbH, Germany). The gas volume balance in UGS was monitored and controlled with $p / z$ curves, and mathematical modelling.
\end{abstract}

Keywords: underground gas storage, underground storage gas-tightness, safety of gas storage, operational parameters of gas storage

https://doi.org/10.7494/978-83-66727-47-2_1 


\section{Wstęp}

Gaz ziemny jest nie tylko ważnym źródłem energii pierwotnej, ale także źródłem energii wykorzystywanym w procesach produkcyjnych do wytwarzania energii elektrycznej lub do ogrzewania komunalnego czy też indywidualnego. Zaopatrzenie w gaz ziemny w Republice Czeskiej (ČR) oparte jest praktycznie w 100\% na surowcu pochodzącym z importu. Dominującymi dostawcami są: Rosja i Norwegia. W ostatnim czasie rośnie również udział gazu ziemnego pozyskiwanego z rynków giełdowych Unii Europejskiej.

System przesyłu gazu w Republice Czeskiej jest zaawansowany technicznie, a szczególną rolę odgrywa jego funkcja tranzytowa. Dominującym kierunkiem tranzytowym gazu jest jego przesył na kierunku wschód - zachód, przy łącznej przepustowości gazociągów $51 \mathrm{mld} \mathrm{Nm}^{3} /$ rok z kierunku wschodniego i $29 \mathrm{mld} \mathrm{Nm}^{3} /$ rok z kierunku zachodniego, a od czasu ukończenia budowy gazociągu Gazela w 2012 roku (o przepustowości $30 \mathrm{mld} \mathrm{Nm}^{3} /$ rok) gaz jest również transportowany przez Republikę Czeską na kierunku północ-południe (Gas Infrastructure Europe, b.d.).

W systemie przesyłowo-dystrybucyjnym wykorzystywane są system połączeń z rurociągami sąsiednich krajów (Niemcy, Słowacja, Polska) oraz podziemne magazyny gazu. Podziemne magazyny gazu (PMG) w Republice Czeskiej mają obecnie łączną pojemność liczoną na ok. 3,442 mld $\mathrm{Nm}^{3}$, co stanowi 35-40\% krajowego rocznego zużycia przy zdolności poboru gazu od $55 \mathrm{mln} \mathrm{Nm}^{3} /$ dobę (początek sezonu pobierania) do $33 \mathrm{mln} \mathrm{Nm}^{3} /$ dobę (koniec sezonu pobierania). Przyjęte założenia polityki energetycznej w Czechach nakierowane są na ciągłe zwiększanie udziału gazu ziemnego jako podstawowego nośnika energii w ogólnym bilansie energetycznym kraju. Założenia polityki energetycznej przewidują, że do 2040 roku gaz ziemny umożliwi stopniowe odejście od stosowania paliw stałych (węgla kamiennego i brunatnego) jako nośników energii. Stanie się on podstawowym produktem energetycznym szczególnie dla małych systemów ciepłowniczych. Będzie również pełnił rolę bufora dla sektora energetyki węglowej oraz pozwoli na częściowe odejście od paliw płynnych w transporcie drogowym (Ministerstvo průmyslu a obchodu 2019: s. 45-46).

\section{Niezawodność i bezpieczeństwo pracy PMG}

Podziemne magazyny gazu (PMG) służą głównie do uzupełniania niedoborów gazu podczas sezonowego zwiększonego zapotrzebowania, a także wspomagają płynną pracę systemów przesyłu i dystrybucji gazu. Podstawowym warunkiem spełnienia tych funkcji jest niezawodność i bezpieczeństwo działania podziemnego magazynu - szcze- 
gólnie istotna jest jego gazoszczelność. Ze względu na charakter działalności związanej z magazynowaniem gazu naturalnym wymogiem operatorów PMG jest eksploatacja magazynów na najwyższym poziomie efektywności, tj. przy maksymalnych parametrach pracy i akceptowalnych kosztach inwestycyjnych oraz eksploatacyjnych. $\mathrm{O}$ ile pierwotne założenia dotyczące stosowania instalacji magazynujących gaz ziemny były podyktowane potrzebą zrównoważenia zmian ilości przesyłanego gazu w sieciach dystrybucyjnych, o tyle obecne i przyszłe wykorzystanie magazynów będzie koncentrowało się głównie na ich wydajności, elastyczności i zmienności magazynowych ilości oraz znacznie większej dynamice procesów dostawy zmagazynowanego gazu.

Z powyższego wynika, że charakterystyka pracy PMG powinna być elastyczna, umożliwiająca uzyskanie jak największej pojemności magazynowania. Zwiększanie pojemności magazynowania gazu w PMG wiąże się zachowaniem gazoszczelności struktur, w których zlokalizowany jest magazyn. Ogólnie gazoszczelność podziemnej części magazynowej PGM dzieli się na gazoszczelność pierwotną (zastaną) i wtórną, zależną od przeprowadzonych zabiegów technicznych (tzn. antropogenicznej działalności człowieka) (Ahmed 2010, Bujok i in. 2019, Horáková 2020).

Gazoszczelność pierwotna podziemnych magazynów gazu ulokowanych w strukturach geologicznych związana jest ze szczelnością złożową tych struktur w wymiarze czasu geologicznego. O szczelności tej świadczy istnienie pułapki zbiornikowej, która była nasycona pierwotnie np. węglowodorami. Znajomość możliwości uwięzienia składowanego gazu w strukturze geologicznej oraz zmiany w zakresie akumulacji gazu przy jednoczesnych zmianach ciśnienia w magazynie jest niezbędne do prognozowania procesu rozwoju PMG. Dane te są określane i kontrolowane za pomocą specjalnych procedur inżynierii złożowej. Może to być np. monitorowanie tzw. krzywej p/z lub wykorzystanie modelowania matematycznego.

Gazoszczelność wtórna magazynów gazu jest definiowana jako zmiana szczelności pierwotnej, która zachodzi w związku z działalnością antropogeniczną człowieka. Zmiany gazoszczelności zbiorników magazynujących gaz mogą zachodzić w sposób bezpośredni - w wyniku działalności wiertniczej zarówno na etapie wykonania odwiertów eksploatacyjnych, w trakcie ich eksploatacji, jak i po ich późniejszej likwidacji. Do zmiany gazoszczelności może też dochodzić w sposób pośredni - na skutek nadmiernego wzrostu ciśnień w formacji kumulującej gaz (związanego ze wzrostem całkowitej ilości magazynowanego gazu), powodującego naruszenie pierwotnego strukturalnego uszczelnienia geologicznego (Horáková 2020).

Uszczelnienie podziemnych zbiorników może następować na skutek zmian tektonicznych w górotworze, zmian facjalnych, litologicznych lub stratygraficznych (Zákopčan 2003, Azin i in. 2008, Wang 2009). 


\section{Czynniki związane z eksploatacją PMG i ich wpływ na gazoszczelność geologicznych struktur magazynujących}

Do szacowania zasobów węglowodorów w złożu powszechnie stosowane jest równanie bilansu masowego MBE (material balance equation). Jest ono jedną z szeregu metod inżynierii złożowej, która może posłużyć do oceny charakteru pracy podziemnego magazynu gazu. Ogólne równanie to dla zbiorników gazu wyraża się następującym wzorem (Ahmed 2010):

$$
\frac{p_{s c} G_{p}}{R T_{s c}}=\frac{p_{i} V}{z_{i} R T}-\frac{p\left[V-\left(W_{e}-W_{p}\right)\right]}{z R T}
$$

gdzie:

$p_{s c}-$ ciśnienie normalne [Pa],

$G_{p}$ - skumulowana ilość wydobytego gazu $\left[\mathrm{Nm}^{3}\right]$,

$R$ - uniwersalna stała gazowa, $R=8,314462 \mathrm{~J} /(\mathrm{K} \cdot \mathrm{mol})$,

$T_{s c}$ - temperatura normalna [K],

$p_{i}$ - początkowe ciśnienie złożowe [MPa],

$V$ - początkowa objętość gazu w złożu $\left[\mathrm{m}^{3}\right]$,

$z_{i}$ - współczynnik ściśliwości gazu dla $p_{i}[-]$,

$T$ - temperatura złożowa $[\mathrm{K}]$,

$p$ - aktualne ciśnienie złożowe $[\mathrm{Pa}]$,

$W_{e}-$ skumulowany dopływ wody $\left[\mathrm{m}^{3}\right]$,

$W_{p}$ - skumulowana produkcja wody $\left[\mathrm{m}^{3}\right]$,

$z$ - współczynnik ściśliwości gazu dla $p[-]$.

Graficzne przedstawienie przekształconego równania (1), czyli tak zwanej krzywej $p / z$, może zostać użyte między innymi do określenia zmiany zasobów w magazynie gazu, stopnia aktywności wód złożowych w magazynie i innych parametrów operacyjnych (Ahmed 2010).

Krzywe $p / z$ przedstawiają funkcjonalną zależność pomiędzy ilorazem $p$ i $z$ (tj. stosunek ciśnienia złożowego gazu do współczynnika ściśliwości - $p / z$ ) a zmianą zasobów gazu w magazynie podczas fazy jego zatłaczania i odbioru. W przypadku rozruchu podziemnego magazynu gazu korzystając z krzywych $p / z$, można śledzić sposób funkcjonowania warstw magazynujących gaz oraz przebieg cyklicznego składowania gazu podczas jego zatłaczania i odbierania.

Krzywe $p / z$ przygotowywane na podstawie danych uzyskanych podczas eksploatacji PMG można również wykorzystać do monitorowania pierwotnej gazoszczelności 
warstw magazynujących gaz. W tym celu używając krzywych $p / z$, analizuje się przebieg zmian ciśnień i ilości gazu zatłoczonego do złoża (magazynu) w funkcji czasu. Analiza taka pozwala na określenie, czy w magazynie gazu pojawiają się ubytki gazu, co wskazywałoby na jego migrację ze struktury magazynowej i utratę szczelności.

Jeżeli porównanie nachylenia krzywych $p / z$ wyznaczonych z przebiegu następujących po sobie cykli zatłaczania i odbierania gazu w poszczególnych sezonach wykaże, że linie zatłaczania i odbierania gazu pokrywają się rok do roku, oznacza to, że nie następuje utrata zasobów gazu z warstw magazynujących. W przypadku utraty zasobów gazu w magazynie krzywe na wykresie zmniejszają kąt nachylenia w stosunku do osi pojemności magazynu, co wskazuje na zwiększenie ilości gazu w magazynie przy tych samych wartościach ilorazu $p / z$ (zmierzonych w poprzednich latach).

W przypadku zbiorników magazynowych typu „aquifer” (w warstwach zawodnionych) i zbiorników magazynowych z wyraźnym naporem wodnym pojemność rzeczywistą magazynu oblicza się dopiero po zatłoczeniu zbiornika do jego pełnej (100\%) pojemności czynnej (Zákopčan 2003).

W magazynach gazu wyróżnia się trzy podstawowe charaktery ich pracy: ekspansyjny (rozprężny), wodny i mieszany.

Tryb ekspansyjny (rozprężny) jest typowy dla PMG, które zajmują całą objętość zbiornika przy ograniczonym dopływie wody do zbiornika magazynującego. Złoża te są zamkniętymi pułapkami, w których woda złożowa została zasadniczo całkowicie wyparta przez pierwotny gaz złożowy. Efekt wpływu ciśnienia wody złożowej w magazynie jest nieobecny lub znikomy. Zależność funkcyjna pomiędzy wielkością ilorazu $p / z$ a ilością magazynowanego gazu $G_{p}$ w tego typu PMG jest liniowa.

Czysto wodny charakter pracy PMG jest raczej teoretycznym wariantem, w którym to straty energii złożowej w zbiorniku są w pełni kompensowane przez dopływ do zbiornika wód okalających lub podściełających.

Natomiast w zbiorniku magazynowym o mieszanym charakterze pracy energia złożowa generowana jest przez działanie dwóch obecnych w przestrzeni zbiornikowej PMG faz, a związana jest z ciśnieniem przemieszczających się wód złożowych ze strefy wodonośnej oraz gazu zmagazynowanego w przestrzeni porowej. W odróżnieniu od klasycznego rozprężnego charakteru pracy magazynu każdemu wzrostowi lub spadkowi ciśnienia podczas pracy zbiornika typu mieszanego towarzyszy przemieszczanie się wody w złożu, co przejawia się różnymi wartościami ciśnień podczas zatłaczania oraz odbierania gazu z magazynu. Przemieszczanie się wód złożowych powoduje, że zależność wartości ilorazu $p / z$ od ilości wydobytego gazu $G_{p}$ ma kształt histerezy (Zákopčan 2003). Im bardziej kształt krzywej p/z odbiega od zależności liniowej, tym większy wpływ na pracę magazynu ma efekt jego strefy zawodnionej (Zákopčan 2010). 
Cykliczny charakter pracy PMG charakteryzuje się częstymi i szybkimi zmianami ilości magazynowanego gazu. Zmiany te mają wpływ na intensywność ruchu wody w magazynie o mieszanej charakterystyce pracy. Zjawisko to jest spowodowane różnicami w przepuszczalności fazowej płynów złożowych (wody i gazu). Zmiany dopływu wody można śledzić tylko w dłuższym okresie. Zmiany te odzwierciedlają prawidłowy dobór zakresu ciśnienia roboczego magazynu. Zaburzenie równowagi w cyklicznej pracy PMG może objawiać się albo zmniejszeniem wolnej objętości przestrzeni porowej dostępnej dla gazu, tj. jej zawodnieniem, albo efektem odwrotnym - cofnięciem się strefy zawodnienia, a tym samym zwiększeniem wolnej objętości przestrzeni porowej PMG. W tym drugim przypadku w niektórych przypadkach może się pojawić niebezpieczeństwo utraty szczelności magazynu.

Przesunięcie granic strefy zawodnionej następuje, gdy ciśnienie w przestrzeni porowej i ciśnienie w części zawodnionej się różnią. W zależności od wartości różnicy ciśnienia dochodzi do przesunięcia konturu woda-gaz w kierunku zwiększenia objętości dla magazynowanego gazu (odepchnięcie wód złożowych i powiększenie objętości magazynowej) lub zmniejszenia dostępnej objętości magazynowej dla gazu (napłynięcie wód złożowych w kierunku części porowej magazynującej gaz).

Zmiana położenia granicy woda-gaz jest zjawiskiem niepożądanym w trakcie normalnej eksploatacji PMG. Zmiana ta jest dopuszczalna jedynie na etapie konwersji zbiornika (przekształcania w PMG), gdy przestrzeń magazynowa jest powiększana przez rozbudowę części gazowej do wymaganej objętości lub gdy pojemność magazynowa jest zwiększana w sposób kontrolowany. Rozszerzenie przestrzeni magazynowej jest jednak możliwe tylko do momentu, w którym dojdzie do wytłoczenia granicy wodagaz poza strukturę zbiornika i ucieczki zmagazynowanego gazu poza strukturalne uszczelnienie (Zákopčan 2003).

\section{Matematyczne modelowanie magazynów gazu i ich parametrów operacyjnych}

Celem matematycznego modelowania jest stworzenie statycznego trójwymiarowego modelu geologicznego magazynu (złoża) oraz modelu dynamicznego przepływu płynów złożowych w magazynie. Przygotowane modele następnie kalibruje się i wykorzystuje do prognozowania dynamicznego zachowania się PMG w trakcie zatłaczania i odbierania z niego gazu. Przygotowany model zazwyczaj jest aktualizowany raz do roku z uwzględnieniem danych z poprzedniego sezonu zatłaczania i odbierania gazu. Po uwzględnieniu danych z poprzedniego sezonu prognozuje się zachowanie magazy-

nu w następnym sezonie operacyjnym (Horáková 2020). 


\section{Porównanie eksploatacji różnego rodzaju podziemnych magazynów gazu należących do MND a.s.}

Do analizy pracy podziemnych magazynów gazu wybrano dwa różne rodzaje obiektów magazynowych. Oba z nich należą do firmy MND a.s. W analizie uwzględniono PMG Uhřice, który jest klasycznym magazynem zlokalizowanym w wyeksploatowanym złożu gazowym, oraz PMG Hähnlein - magazyn typu „,aquifer”, zlokalizowany w warstwach wodonośnych. Położenie obu magazynów przedstawia rysunek 1.

a)

b)

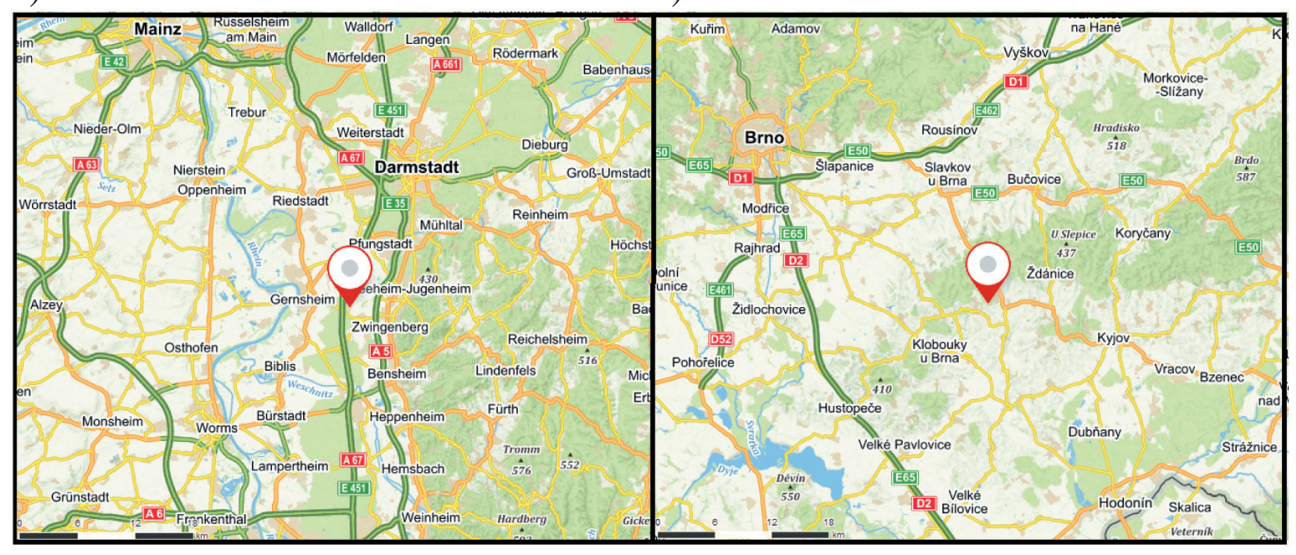

Rys. 1. Lokalizacja wybranych do analizy magazynów:

a) PMG Hähnlein w RFN; b) PMG Uhřice na terenie Republiki Czeskiej

Źródło: www.mapy.cz

\subsection{Podziemny magazyn gazu Uhřice}

PMG Uhřice znajduje się w obrębie administracyjnym miejscowości Uhřice (rys. 1) w powiecie Kromieryż. Złoże, w którym wytworzono magazyn, ma kształt półłuku, wydłużonego w kierunku zachodnio-północno-zachodnim oraz wschodnio-południowo-wschodnim z upadem południowo-zachodnim. Magazyn gazu od północy ograniczony jest tektonicznie, a od strony wschodniej zakłada się istnienie zamknięcia erozyjnego. W dolnej strukturze złoża (obecnie magazynu) występuje rozległy kompleks wodonośny. Jest to strukturalno-tektoniczny typ pułapki złożowej w warstwach arenitowych formacji gresteńskiej (rys. 2). Na całym obszarze złoża w struktura nadkładu zbudowana jest z osadów wykształconych głównie jako iły formacji żdanicko-hustopeckiej, jednostki żdanickiej. Złoże gazu związane jest z podstawowymi warstwami jurajskimi arenitami formacji Gresten, która jest kompleksem piaskowcowym (rys. 2). Warstwa zbiornikowa zbudowana jest ze średnio- lub gruboziarnistego piaskowca kwarcytowego, 
miejscami zlepieńcowatego. Miejscami piaskowce kwarcytowe przechodzą w piaskowce arkozowe. Zawartość wapnienia w piaskowcach jest zmienna, ale przeważnie niewielka (ok. 3\%).

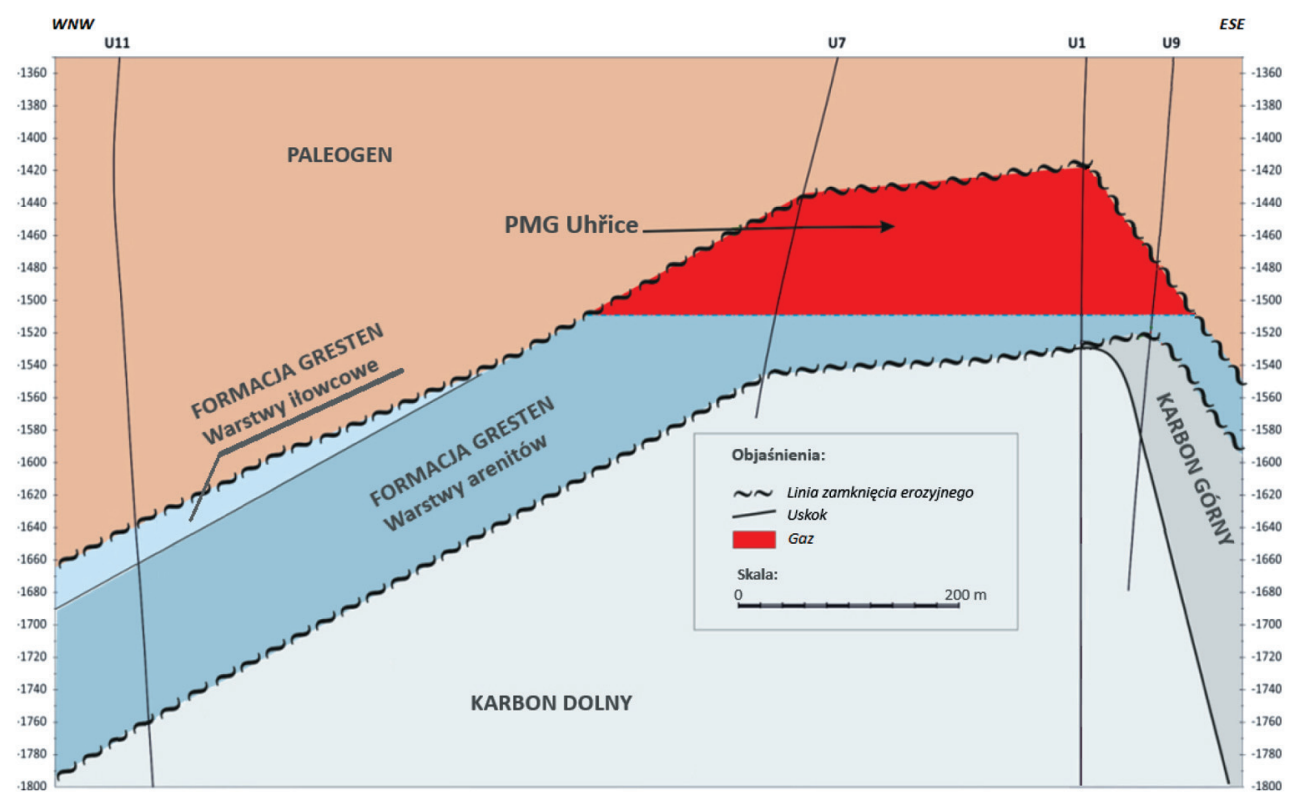

Rys. 2. Podłużny przekrój geologiczny przez podziemny magazyn gazu Uhřice Źródło: opracowanie własne na podstawie Horáková (2020)

Miąższość warstwy magazynowej waha się w przedziale 100-135 m. Warstwą uszczelniającą magazyn w stropie są nadległe ciemne iły. Porowatość efektywna warstwy porowatej waha się w zakresie 10-25\%, a wartości przepuszczalności wynoszą $10-500 \mathrm{mD}\left(\operatorname{od} 0,010 \cdot 10^{-12} \mathrm{~m}^{2}\right.$ do $\left.0,494 \cdot 10^{-12} \mathrm{~m}^{2}\right)$. W horyzoncie występują naprzemiennie miejsca o zwiększonej i zmniejszonej porowatości oraz przepuszczalności. Parametry warstwy magazynującej poprawiają się wraz ze wzrostem głębokości jej zalegania (Horáková 2020). Pierwotną granicę kontaktu gaz-woda w strukturze ustalono na poziomie $-1509 \mathrm{~m}$. Początkowe ciśnienie złożowe związane z płaszczyzną kontaktu woda-gaz wynosi $p=17,022 \mathrm{MPa}$. Temperatura złoża na tej głębokości została określona na poziomie $t=53^{\circ} \mathrm{C}$ (Zákopčan 2003, Horáková 2020).

Konwersję złoża Uhřice na magazyn gazu rozpoczęto w roku 2001, a przekształcanie złoża na w pełni funkcjonalny magazyn trwało do roku 2008. Podstawowe projektowe parametry dla magazynu zestawiono w tabeli 1 .

Podziemny magazyn gazu Uhřice wykorzystuje siedem odwiertów wiertniczych zatłaczająco-odbiorczych. Dodatkowo w obrębie magazynu znajdują się: jeden odwiert wiertniczy monitorujący składowany gaz, jeden odwiert monitorujący wody podściełają- 
ce zbiornik magazynowy oraz jeden odwiert do monitorowania położenia granicy konturu woda-gaz. Ponadto PMG Uhřice wykorzystuje dwa odwierty ulokowane w nadkładzie zbiornika służące do monitorowania szczelności warstw nadkładu magazynu.

Tabela 1

Projektowane parametry podziemnego magazynu gazu Uhřice

\begin{tabular}{|c|c|c|c|}
\hline $\begin{array}{c}\text { Pojemność buforowa } \\
\text { (bierna) } \\
{\left[\mathrm{mln} \mathrm{Nm}^{3}\right]}\end{array}$ & $\begin{array}{c}\text { Pojemność czynna } \\
\text { (aktywna) } \\
{\left[\mathrm{mln} \mathrm{Nm} \mathrm{Nm}^{3}\right]}\end{array}$ & $\begin{array}{c}\text { Pojemność całkowita } \\
{\left[\mathrm{mln} \mathrm{Nm}^{3}\right]}\end{array}$ & $\begin{array}{c}\text { Minimalne } \\
\text { i maksymalne ciśnienia } \\
\text { robocze } \\
{[\mathrm{MPa}]}\end{array}$ \\
\hline 95 & 185 & 280 & $7,5-23,0$ \\
\hline
\end{tabular}

Źródło: opracowanie na podstawie Horáková (2020)

\section{Charakterystyka operacyjna PMG Uhřice}

Tryb pracy PMG ma charakter mieszany, tzn. energia złożowa powstaje w wyniku działania obu faz obecnych w zbiorniku PMG, czyli na skutek działania ciśnienia przemieszczających się wód złożowych oraz rozprężania się zmagazynowanego w przestrzeni porowej gazu.

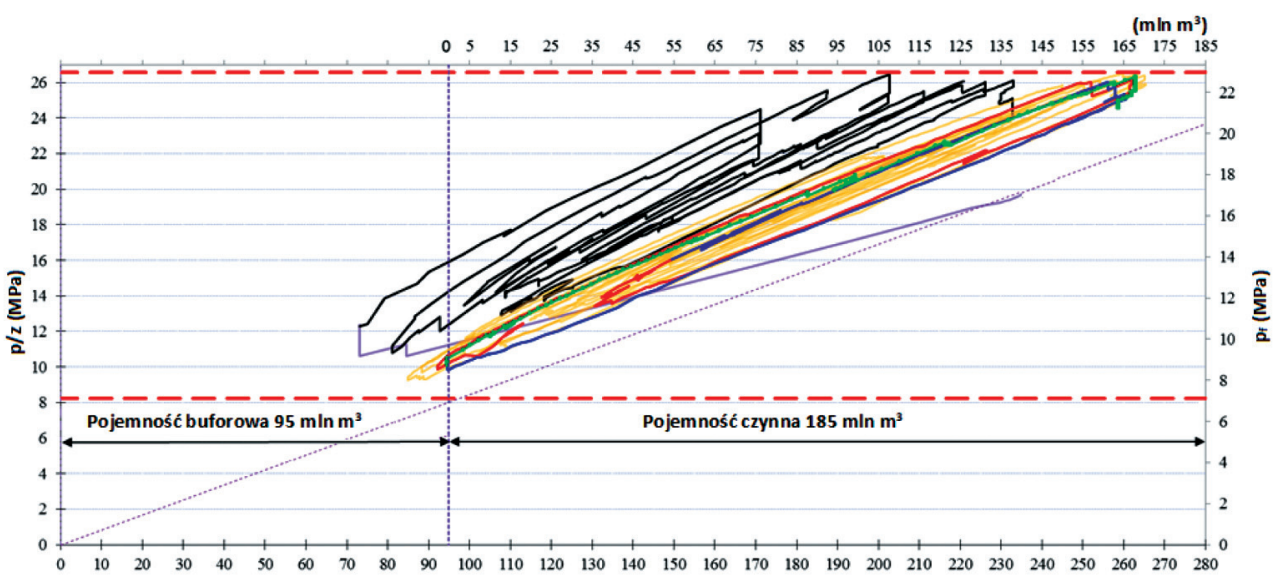

\begin{tabular}{|c|c|c|}
\hline $\begin{array}{l}\text { Pierwotne wydobycie }(1984 \div 1995) \\
\text { - Sezon zattaczania-odbierania 2016/17 } \\
\text { — - } p_{\mathrm{fmax}}(23 \mathrm{M} \mathrm{Pa})\end{array}$ & $\begin{array}{l}\text { - Budowanie magazynu } 2001 \div 2008 \\
- \text { Sezon zattaczania-odbierania } 2017 / 18 \\
\text { - } \operatorname{Pr}_{\mathrm{r} \min }(7,5 \mathrm{M} \mathrm{Pa})\end{array}$ & $\begin{array}{l}\text { Sezon zatłaczania-odbierania } 2008 \div 2016 \\
- \text { Sezon zatlaczania-odbierania } 2018 / 19\end{array}$ \\
\hline
\end{tabular}

Rys. 3. Krzywe $p / z$ dla podziemnego magazynu gazu PMG Uhřice z lat 2001-2019 (przerywaną linią czerwoną zaznaczono maksymalne i minimalne dopuszczalne ciśnienie w zbiorniku podczas normalnej eksploatacji magazynu)

Źródło: opracowanie na podstawie Horáková (2020)

Rysunek 3 przedstawia krzywą $p / z$ dla magazynu gazu Uhřice w okresie konwersji oraz standardowej eksploatacji po zakończeniu okresu przekształcania złoża w magazyn 
gazu. Analiza ewolucji krzywej p/z w trakcie konwersji z lat 2001-2008 wskazuje na stopniowe powiększanie objętości porowej dostępnej dla gazu w PMG, która to ustabilizowała się po roku 2008. Położenie krzywych (rys. 3) p/z w kolejnych latach po okresie konwersji złoża wskazuje, że znajdują się one w tej samej strefie na wykresie, co świadczy o zakończeniu konwersji i o ustabilizowaniu się parametrów pracy magazynu.

\section{Modelowanie matematyczne pracy PMG Uhřice}

Model geologiczny PMG Uhřice został przygotowany w programie Petrel na podstawie pomiarów sejsmicznych 3D rejonu, w którym magazyn się znajduje. Model dynamiczny dla magazynu opracowano natomiast w programie Eclipse. Oba programy są autorstwa firmy Schlumberger.

Do budowy modelu dynamicznego wykorzystano m.in. następujące dane wejściowe: statyczny model geologiczny obiektu, właściwości petrofizyczne skał zbiornikowych, charakterystyki PVT płynów złożowych, pierwotne warunki złożowe, pierwotne zasoby węglowodorów w złożu; informacje o odwiertach, parametry wydajnościowe odwiertów eksploatacyjnych, dane o ciśnieniach złożowych w poszczególnych odwiertach oraz dane o wydobytych zasobach płynów złożowych.

Po uwzględnieniu w modelu symulacyjnym danych wejściowych przygotowano wariantowe symulacje pracy magazynu. W ramach modelowania predykcji pracy magazynu gazu opracowano dwa scenariusze:

1) optymalizacji jego długoterminowej eksploatacji,

2) możliwość osiągnięcia maksymalnej pojemności magazynowej PMG.

Pierwszy scenariusz pracy magazynu gazu Uhřice został zasymulowany w taki sposób, aby odzwierciedlić optymalny reżim pracy. Miał on również za zadanie określenie maksymalnych wartości parametrów operacyjnych (tj. ciśnień oraz strumieni zatłaczania i odbierania gazu) dla zapewnienia długoterminowej stabilnej pracy PMG. Na potrzeby prognozy pracy magazynu w reżimie stabilnym przyjęto, że magazyn będzie pracował w dwóch skrajnych wariantach: przy maksymalnym oraz minimalnym poborze gazu z PMG (Horáková 2020).

Symulacje dla obu wariantów (optymalnego i stabilnego) przeprowadzono w odniesieniu do okresu eksploatacji od 1.01.2010 do 1.12.2015 roku. Oba testowane warianty różniły się sposobem oraz czasem zatłaczania i pobierania gazu z magazynu. Przyjęto też, że pobór gazu z magazynu będzie się odbywał do wartości minimalnego ciśnienia pracy magazynu, tj. $p=7,3 \mathrm{MPa}$ (poniżej tej wartości układ operacyjny nie był w stanie przetłoczyć gazu do międzysystemowego gazociągu, w którym ciśnienie 
robocze wynosi $p=6,1 \mathrm{MPa}$ ). Dla fazy zatłaczania gazu przyjęto natomiast maksymalne ciśnienie na poziomie $p=22,5 \mathrm{MPa}$, które to odpowiadało maksymalnemu początkowemu statycznemu ciśnieniu w wyeksploatowanym złożu.

W tabeli 2 zestawiono parametry operacyjne, które uzyskano w procesie symulacji pracy magazynu dla maksymalnego i minimalnego poboru gazu z magazynu (pierwszy scenariusz).

Tabela 2

Uzyskana charakterystyka poszczególnych wariantów symulacji pracy magazynu

\begin{tabular}{|c|c|c|c|c|c|c|c|c|c|}
\hline \multirow[t]{2}{*}{ Wariant } & 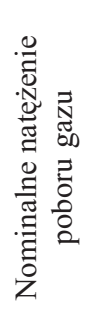 & 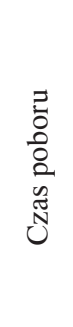 & 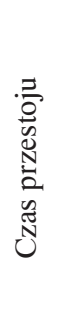 & 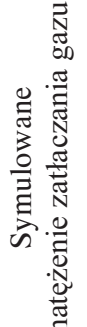 & 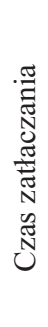 & 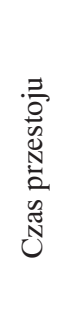 & 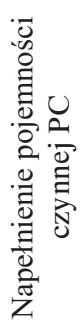 & 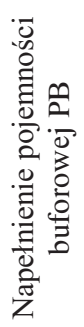 & \multirow{2}{*}{ 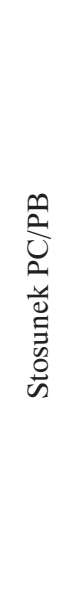 } \\
\hline & 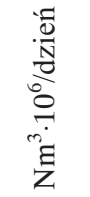 & $\begin{array}{l}\ddot{\Xi} \\
\tilde{\Xi} \\
\tilde{N} \\
.0 \\
.0\end{array}$ & $\begin{array}{l}\cdot \bar{\Xi} \\
\tilde{\Xi} \\
\tilde{N} \\
. \\
:\end{array}$ & 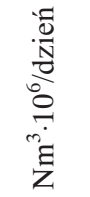 & $\begin{array}{l}\tilde{E} \\
\tilde{E} \\
\tilde{N} \\
.0\end{array}$ & 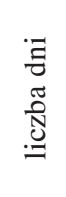 & $\begin{array}{l}\stackrel{0}{\circ} \\
\stackrel{7}{7} \\
\stackrel{\Xi}{z} \\
z\end{array}$ & 号 & \\
\hline \multirow{2}{*}{$\begin{array}{l}\text { Maksymalny } \\
\text { pobór gazu }\end{array}$} & \multirow{2}{*}{6} & \multirow{2}{*}{32} & \multirow{2}{*}{79} & 2,4 & 46 & \multirow{2}{*}{170} & \multirow{2}{*}{156} & \multirow{2}{*}{119} & \multirow{2}{*}{0,76} \\
\hline & & & & 1,2 & 38 & & & & \\
\hline \multirow{2}{*}{$\begin{array}{l}\text { Minimalny } \\
\text { pobór gazu }\end{array}$} & \multirow{2}{*}{1} & \multirow{2}{*}{169} & \multirow{2}{*}{3} & 2,4 & 57 & \multirow{2}{*}{110} & \multirow{2}{*}{169} & \multirow{2}{*}{109} & \multirow{2}{*}{0,65} \\
\hline & & & & 1,2 & 26 & & & & \\
\hline
\end{tabular}

Źródło: opracowanie na podstawie Horáková (2020)

Wyniki modelowania pracy magazynu gazu Uhřice wskazują, że jego stabilna cykliczna praca zależy zarówno od tempa odbioru gazu, jak i przedziału czasu, w którym ciśnienie w gazu w magazynie jest niższe od wartości ciśnienia początkowego w złożu przeznaczonym na magazyn.

Na podstawie wyników symulacji dwóch skrajnych scenariuszy można stwierdzić, że magazyn będzie mógł pracować w zakresie $G=156-169 \mathrm{mln} \mathrm{Nm}^{3}$ gazu przy napełnianiu jego pojemności czynnej i ciśnieniach roboczych $p=10,0-22,5$ MPa (Horáková 2020). W wyniku symulacji okazało się, że modelowany zakres pojemności czynnej 
magazynu podczas eksploatacji odpowiada jego rzeczywistej stabilnej pracy od 2011 roku.

Drugi scenariusz pracy magazynu PMG Uhřice przygotowano w celu ustalenia jego maksymalnej pojemności, co wiąże się określeniem niezbędnego czasu potrzebnego do wyparcia wód złożowych do pierwotnego obrysu (jak w złożu przed rozpoczęciem eksploatacji).

Modelowano dwa warianty (1 i 2) uzyskania maksymalnej pojemności magazynu: pierwszy w przedziale czasu od 1.01.2010 do 1.12.2030 roku, natomiast w przypadku wariantu drugiego skrócono interwał czasu do 30.06.2025 roku. Modelowanie w obu wariantach zakładało cykliczną pracę magazynu w zakresie ciśnienia złożowego (roboczego magazynu) $p=8,4-22,5 \mathrm{MPa}$.

Przy symulowaniu pracy magazynu podczas jego eksploatacji przy założonym powyższym scenariuszu przyjęto dwa różne warianty operacyjne różniące się strategią zatłaczania gazu w okresie zwiększania jego pojemności czynnej. W wariancie pierwszym predykcji pracy magazynu zatłaczanie i odbieranie gazu w całym symulowanym okresie odbywało się w najszerszym możliwym zakresie parametrów operacyjnych, tj. zatłaczanie odbywało się do wartości maksymalnego ciśnienia złożowego $p_{f}=22,5 \mathrm{MPa}$, a pobieranie gazu z magazynu przebiegło przy minimalnym ciśnieniu głowicowym $p=7,3 \mathrm{MPa}$. Zatłaczanie gazu rozpoczynało się zaraz po zakończeniu okresu jego odbierania lub następowało po maksymalnie długim okresie przestoju stabilizującego po zatłoczeniu. Z przeprowadzonych analiz wynika, że z roku na rok stopniowo powinna się zwiększać zarówno ilość zatłoczonego gazu, jak i ilość gazu możliwa do odebrania. W okresie objętym prognozą eksploatacyjną czas odbierania gazu wydłużył się z 32 do 35 dni, natomiast czas jego zatłaczania z 90 do 108 dni. Jednocześnie czas przestoju po zatłoczeniu skrócił się z 242 do 221 dni (tab. 3).

Drugi brany pod uwagę wariant symulowania pracy magazynu polegał na określeniu najkrótszego czasu, w jakim będzie możliwe ograniczenie zawadniania się PMG (przemieszczenie wód złożowych). Predykcja zakładał, że do roku 2019 odbywałoby się jedynie coroczne dotłaczanie gazu do wartości maksymalnego ciśnienia roboczego magazynu. Dopiero po tym czasie rozpoczęłyby się właściwe cykle pracy podziemnego magazynu gazu.

Wariant drugi przewidywał, że do roku 2019 przeprowadza się jedynie coroczne dotłoczenie gazu do maksymalnego ciśnienia złożowego ( $\left.p_{f}=22,5 \mathrm{MPa}\right)$. Zgodnie z symulacją taki sposób operowania magazynem zwiększyłby ilości gazu w PMG o $G=72 \mathrm{mln} \mathrm{Nm}^{3} \mathrm{w}$ ciagu 9 lat. Odbieranie gazu w trakcie cyklu operacyjnego (od 2020 roku) odbywałoby się do minimalnego ciśnienia na głowicy odwiertu równego $p_{g}=7,3 \mathrm{MPa}$.

W tabeli 3 zestawiono parametry, które uzyskano dla drugiego scenariusza symulacji pracy magazynu gazu Uhřice. 
Tabela 2

Zestawienie uzyskanych wartości pracy magazynu dla poszczególnych wariantów symulacji przeprowadzonych dla drugiego scenariusza modelowania

\begin{tabular}{|c|c|c|c|c|c|c|c|c|c|}
\hline \multirow[t]{2}{*}{ Wariant } & 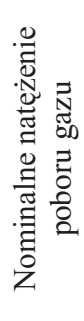 & 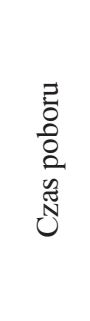 & 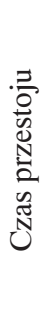 & 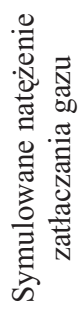 & 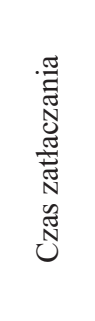 & 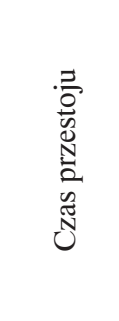 & 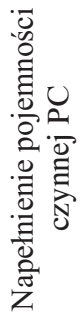 & 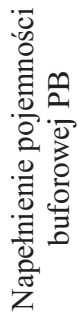 & \multirow{2}{*}{ 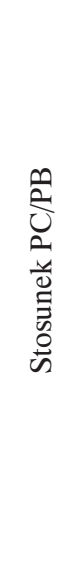 } \\
\hline & 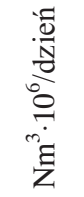 & 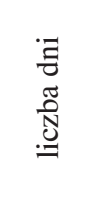 & 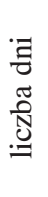 & 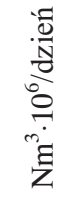 & $\begin{array}{l}\vec{\Xi} \\
\tilde{\Xi} \\
\tilde{N} \\
. \mathscr{N}\end{array}$ & 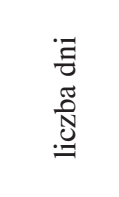 & $\begin{array}{l}\stackrel{0}{\circ} \\
\stackrel{1}{7} \\
\stackrel{1}{z}\end{array}$ & 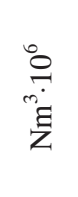 & \\
\hline \multirow{2}{*}{1} & \multirow{2}{*}{6} & \multirow{2}{*}{$32-35$} & \multirow{2}{*}{1} & 2,4 & 46 & \multirow{2}{*}{$242-221$} & 157 & 118 & 0,75 \\
\hline & & & & 1,2 & $44-62$ & & 185 & 146 & 0,78 \\
\hline \multirow{4}{*}{2} & \multirow{4}{*}{6} & \multirow{4}{*}{45} & \multirow{4}{*}{1} & 3,5 & 10 & \multirow{3}{*}{91} & \multirow{4}{*}{215} & \multirow{4}{*}{141} & \multirow{4}{*}{0,66} \\
\hline & & & & 3,0 & 21 & & & & \\
\hline & & & & 2,4 & 69 & & & & \\
\hline & & & & 1,0 & 5 & 124 & & & \\
\hline
\end{tabular}

Źródło: opracowanie na podstawie Horáková (2020)

W przypadku obu symulowanych wariantów gaz pobierany był, zgodnie z krzywą zapotrzebowania, z maksymalną mocą równą $Q=6 \mathrm{mln} \mathrm{Nm}^{3} /$ dzień. W celu uniknięcia napływu wody złożowej do struktury magazynowej zatłaczanie magazynu rozpoczyna się następnego dnia po zakończeniu odbierania gazu. Dzięki temu i przy maksymalnym czasie przestoju zbiornika po jego załłoczeniu według pierwszego z symulowanych wariantów w magazynie dochodzi do cyklicznego powiększania się ilości magazynowanego gazu z każdym kolejnym rokiem, a prognozowane zwiększenie objętości magazynowanego gazu w ciągu następnych 20 lat wzrasta z $G=275 \mathrm{mln} \mathrm{Nm^{3 }}$ do $G=331 \mathrm{mln} \mathrm{Nm}^{3}$. Jednak w tym przypadku, jak wskazują wyniki symulacji, zawodnienie przestrzeni złożowej powstałe w wyniku pierwotnej eksploatacji złoża nie zostanie w pełni odwrócone, tzn. nie nastąpi przemieszczenie wody do pierwotnego położenia konturu nawet do roku 2030 (Zákopčan 2010). 
Cykl pracy magazynu gazu w wyeksploatowanych złożach gazu zakłada sezonowość pracy takiego zbiornika, która polega na tym, że pracuje on w roku przy jednym pełnym cyklu (pełny cykl to jednokrotne zatłoczenie i odebranie gazu).

Przy intensywnym wykorzystaniu magazynu zwiększałoby to akumulację gazu w magazynie przy jednoczesnym niewykorzystaniu części pojemności dostępnej dla gazu zmagazynowanego w jego pojemności czynnej. W przypadku magazynów gazu zlokalizowanych w wyeksploatowanych złożach węglowodorów przyjmuje się, że mniej więcej połowa pojemności magazynu jest pojemnością czynną, w której magazynowany jest gaz roboczy. Druga połowa magazynu kumuluje gaz w tzw. pojemności buforowej (pojemność bierna, nieużytkowa), która musi być utrzymywana w sposób ciągły w magazynie, pozwalając na prawidłowe jego funkcjonowanie (zapewnia odpowiednie ciśnienie robocze magazynu, stanowi barierę dla napierających wód złożowych). Dlatego przy eksploatacji magazynu gazu należy brać pod uwagę fakt, że w miarę stopniowego zwiększania jego pojemności czynnej, konieczne jest równoczesne zwiększanie jego pojemności buforowej mniej więcej w takiej samej proporcji, o jaką zwiększa się pojemność czynną. Powoduje to zwiększanie „nieużytecznej” pojemności gazu w magazynie, a to wpływa na koszty magazynowania gazu.

Przeprowadzone symulacje wskazują, że możliwa byłaby dalsza rozbudowa magazynu gazu Uhřice w przypadku obu testowanych wariantów. Możliwość powiększenia pojemności magazynu zależałaby w szczególności od poziomu bezpieczeństwa szczelności magazynu (pod względem budowy geologicznej raczej nie ma znacznego ryzyka bocznych ucieczek gazu). Dalsze zwiększanie pojemności magazynu w obecnym stanie wydaje się ograniczone z powodu niewystarczającej liczby odwiertów zatłaczająco-odbierających. Ze względu na aktualną ich liczbę i przepustowość nie byłyby one w stanie obsłużyć zbiornika o tak dużej pojemności czynnej (Horáková 2020). W rzeczywistych warunkach pracy zbiornika osiągnięto maksymalną pojemność czynną magazynu równą $G=172,5 \mathrm{mln}^{2} \mathrm{Nm}^{3}$ przy maksymalnym ciśnieniu roboczym $p_{f}=22,9 \mathrm{MPa}$. Należy zauważyć, że PMG Uhřice jest obecnie stabilnie eksploatowany przy poduszce gazowej (pojemności buforowej) równej $Q=95 \mathrm{mln} \mathrm{Nm}^{3}$, co stoi w sprzeczności z wariantami modelowymi i wymaganiami zwiększenia pojemności buforowej gazu w magazynie.

\subsection{Podziemny magazyn gazu Hähnlein}

Podziemny magazyn gazu Hähnlein jest zlokalizowany w Niemczech (patrz rys. 1), w południowej części kraju związkowego Hesja.

Struktura geologiczna zbiornika to płaskie, słabo sklepione antyklinorium wydłużone w kierunku północno-południowym. Magazyn ograniczony jest od wschodu głównym uskokiem (jednym z kilku w tym rejonie), który zapada w kierunku zachodnim. 
Od strony zachodniej struktura ograniczona jest innym uskokiem, którego największe przesunięcie wynosi około $70 \mathrm{~m}$ i przesunięcie to zimniejsza się w kierunku północnym i południowym. Dalej na zachód (za uskokiem) przebiega wąskie, południkowo zorientowane wypiętrzenie, które jest najprawdopodobniej elementem przejściowym do płaskiego wzniesienia leżącego na zachód od głównej struktury zbiornikowej (rys. 4). Głębokość zalegania tego horyzontu waha się w granicach 498-523 m (Dierking i in. 1999, Horáček i in. 2017).

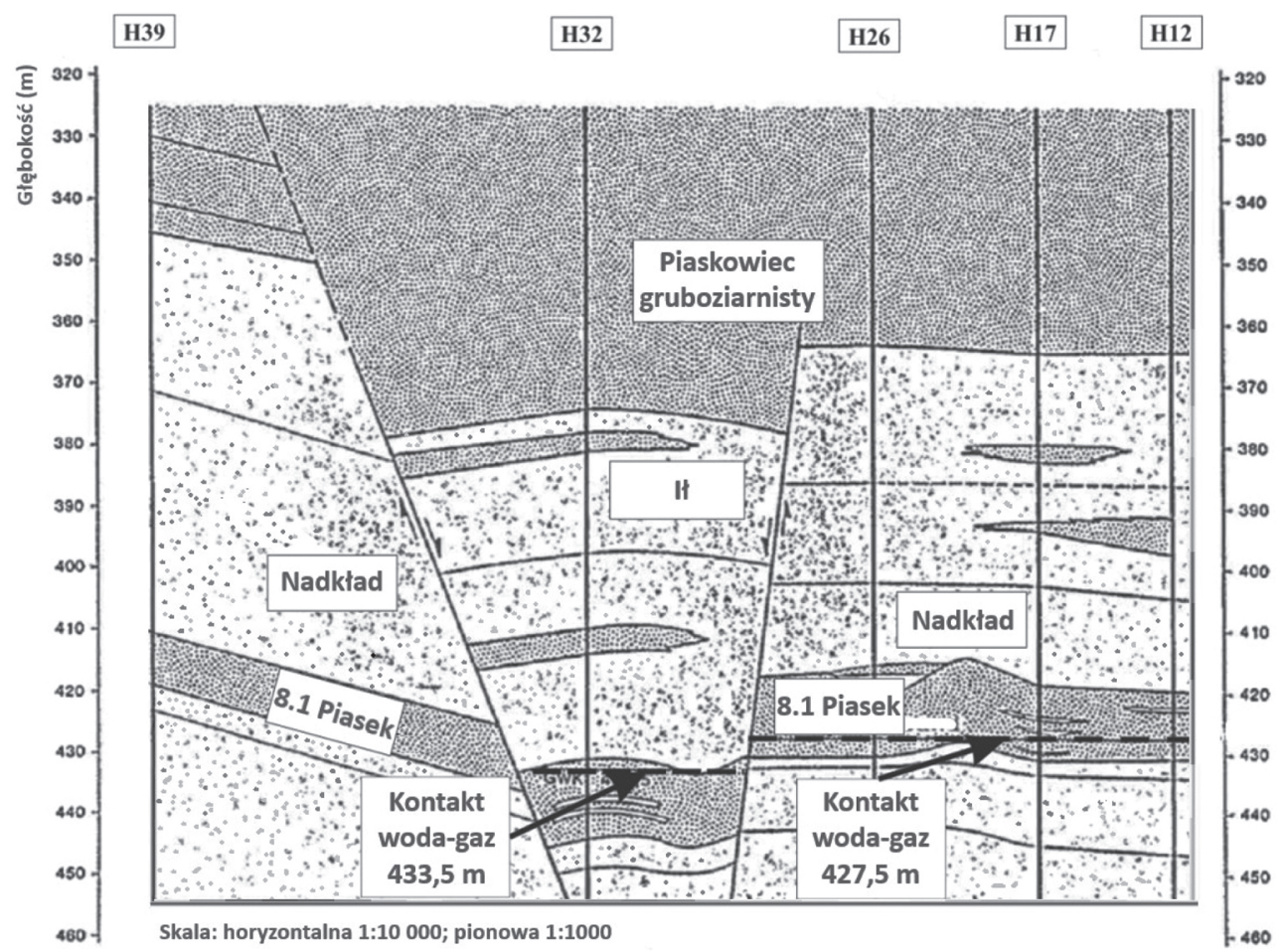

Rys. 4. Przekrój geologiczny złoża PMG Hähnlein

Źródło: zmodyfikowany na podstawie Dierking i in. (1999)

Pod względem litologicznym warstwa magazynująca to bardzo słabo skonsolidowany, drobnoziarnisty piaskowiec z przewarstwieniami iłowcami. Generalnie miąższość horyzontu magazynowego zawiera się w granicach 10-19 m. Właściwie magazyn gazu składa się z kilku warstw piaskowców przewarstwionych iłowcami, a ich miąższość waha się od kilku centymetrów do kilku metrów. Dlatego też należy przyjąć, że każda z warstw wchodzących w skład kompleksu magazynowego ma swój lokalny zasięg i może mieć odmienne własności hydrodynamiczne. Miąższość efektywna warstwy magazynowej stanowi około 55\% całkowitej miąższości magazynu. Warstwa magazynująca gaz cechuje się zmienną porowatością - w przedziale 20-30\% z medianą wynoszącą 25\%. 
Szacowana przepuszczalność magazynu określona na podstawie badań rdzeni wiertniczych wynosi 0,9869 $10^{-12} \mathrm{~m}^{2}$ ( 1000 mD) (Heymer i Dierking 1993). Magazyn gazu jest uszczelniony w stropie przez pokrywę składającą się z kompleksu łupków i iłowców wapnistych o miąższości ok. 50-55 m. Do monitorowania szczelności struktury magazynu używana jest pierwsza warstwa piaskowca zalegająca w nadkładzie strefy magazynowej. W PMG Hähnlein do składowania gazu wykorzystuje się tzw. piasek 8.1 (rys. 4), który przed utworzeniem magazynu był warstwą wodonośną („aquifer”).

Konwersja horyzontu piasku 8.1 do magazynu gazu rozpoczęła się we wrześniu 1960 roku, kiedy to zaczęto zatłaczanie do niego gazu świetlnego. Następnie na przełomie roku 1973 i 1974 rozpoczęto konwersję magazyn na podziemny magazyn gazu ziemnego. Podstawowe parametry PMG Hähnlein zostały zestawione w tabeli 4.

Tabela 4

Parametry podziemnego magazynu gazu Hähnlein

\begin{tabular}{|c|c|c|c|}
\hline $\begin{array}{c}\text { Pojemność buforowa } \\
\text { (pasywna) } \\
{\left[\mathrm{mln} \mathrm{Nm}^{3}\right]}\end{array}$ & $\begin{array}{c}\text { Pojemność czynna } \\
\text { (aktywna) } \\
{\left[\mathrm{mln} / \mathrm{Nm}^{3}\right]}\end{array}$ & $\begin{array}{l}\text { Pojemność całkowita } \\
{\left[\mathrm{mln} \mathrm{Nm}^{3}\right]}\end{array}$ & $\begin{array}{c}\text { Minimalne } \\
\text { i maksymalne ciśnienia } \\
\text { robocze } \\
{[\mathrm{MPa}]}\end{array}$ \\
\hline 80 & 80 & 160 & $3,0-5,4$ \\
\hline
\end{tabular}

Źródło: opracowanie na podstawie Horáková (2020)

W obrębie magazynu Hähnlein zlokalizowanych jest 19 odwiertów zatłaczająco-odbierających oraz trzy odwierty monitorujące pracę magazynu, przy czym jeden z nich przeznaczony jest do monitorowania nadkładu magazynu.

Ze względu na konieczność separowania z odbieranego z magazynu gazu zawartej w nim wody w magazynie wykorzystywany jest jeszcze jeden dodatkowy odwiert, którym powrotnie do magazynu zatłaczana jest odseparowana woda złożowa.

\section{Charakterystyka operacyjna PMG Hähnlein}

Pierwotne ciśnienie złożowe w warstwie złożowej zmierzone w roku 1960 wynosiło $p=5,2 \mathrm{MPa}$, po czym na koniec 1973 roku wynosiło ono $p=5,44 \mathrm{MPa}$. Na przełomie lat 1983/1984 maksymalne ciśnienie robocze magazynu zostało obniżone do $p=5,4 \mathrm{MPa}$, a całkowitą ilość gazu w magazynie zmniejszono do $G=160 \mathrm{mln} \mathrm{Nm}^{3}$. Czynnikiem, który wymusił obniżenie ciśnienia roboczego magazynu i składowanej ilości gazu, było przesunięcie się konturu kontaktu gaz-woda, które zostało spowodowane zatłoczeniem łącznej ilości gazu $G=200 \mathrm{mln} \mathrm{Nm}^{3}$ do warstw magazynujących, w wyniku czego ciśnienie złożowe osiągnęło wartość $p=5,8 \mathrm{MPa}$. Do przesunięcia położenia konturu woda-gaz doszło z powodu przekroczenia wartości bezpiecznych ciśnień dla poziomów uszczelnień tektonicznych. W następstwie tego doszło do ucieczek gazu do pozamaga- 
zynowej warstwy przepuszczalnej. Ponadto wpływ na ucieczki gazu, czego nie można wykluczyć, mogły mieć również procesy chemiczne związane z degradacją składowanego we wczesnym okresie działania magazynu gazu świetlnego. Szacuje się, że do 1987 roku wystąpiły ucieczki gazu o prawdopodobnej łącznej ilości około $Q=35,4 \mathrm{mln} \mathrm{m}^{3}$. Zmusiło to operatora magazynu do odjęcia tej wartości od łącznych zasobów gazu w magazynie. Po obniżeniu parametrów operacyjnych pracy magazynu jego eksploatacja stała się stabilna i nie notowano dalszych ucieczek gazu w kierunku przypuszczalnych warstw zlokalizowanych poza magazynem (Heymer i Dierking 1993).

$\mathrm{Na}$ rysunku 5 przedstawiono krzywą $p / z$ z okresu magazynowania gazu w PMG Hähnlein w tzw. piasku 8.1 z lat 1987-2019.

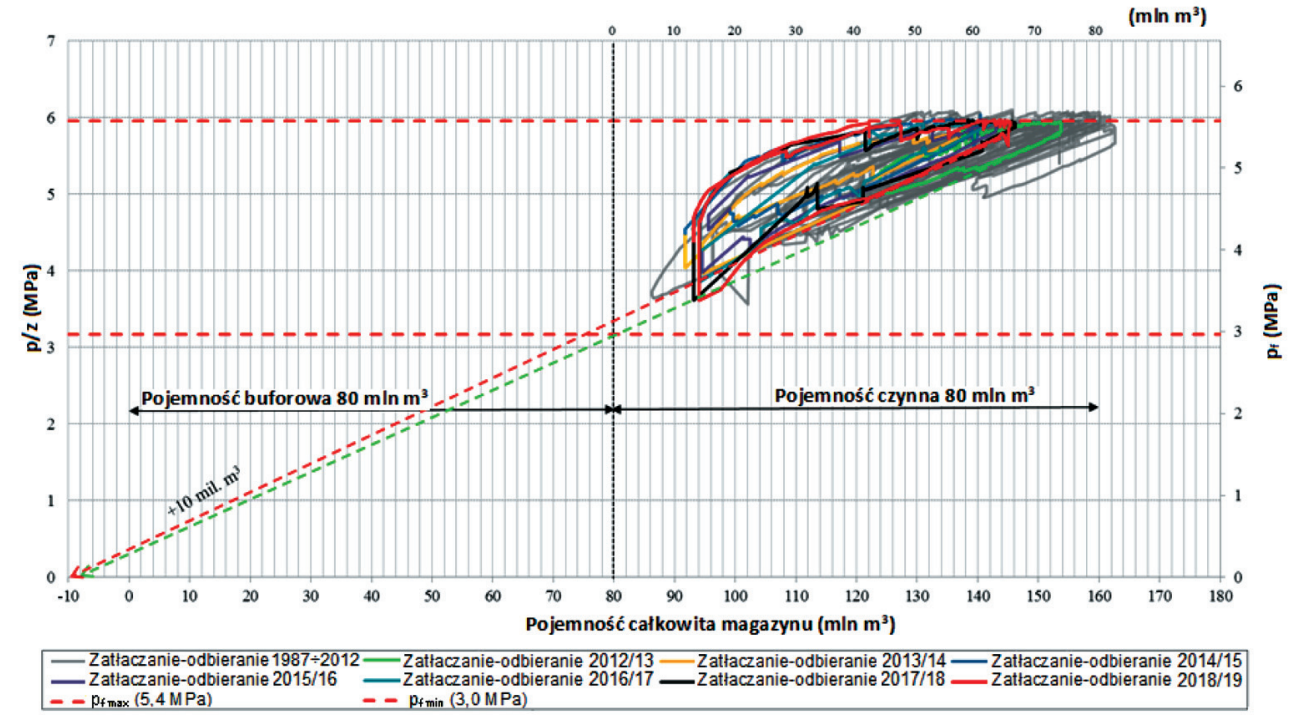

Rys. 5. Krzywa $p / z$ dla PMG Hähnleina z okresu od roku 1987 do roku 2019 Źródło: opracowanie na podstawie Horáková (2020)

Ewolucja przebiegu krzywej $p / z$ dla magazynu wskazuje na mieszany tryb jego pracy. Energia złożowa powstaje w wyniku działania obu obecnych w przestrzeni magazynu faz, a mianowicie ciśnienia wywołanego przez przemieszczające się wody złożowe oraz ciśnienia gazu zmagazynowanego w przestrzeni porowej (liniami przerywanymi zaznaczono maksymalne i minimalne ciśnienie w magazynie gazu).

Porównanie przebiegu krzywej $p / z$ w funkcji ilości wydobytego gazu $\mathrm{z}$ ewidencją zasobów magazynu w szczególności z cyklu w roku 2012/2013 (linia koloru jasnozielonego) wskazuje, że w złożu znajdowało się o $Q=10 \mathrm{mln} \mathrm{Nm}^{3}$ gazu więcej niż w ewidencji inwentarzowej. Nachylenie krzywej $p / z$ jest podobne w kolejnych sezonach pracy magazynu, aż do sezonu 2018/2019 (linia czerwona). 
W latach 2016-2019 z magazynu Hähnlein nie udało się odebrać całej zmagazynowanej ilości gazu w jego pojemności czynnej. W magazynie pozostało $G=13,2-14,1 \mathrm{mln} \mathrm{Nm}^{3}$ gazu przy ciśnieniu złożowym odpowiednio na poziomie $p=3,4-3,5 \mathrm{MPa}$. Niemożność odebrania całej czynnej ilości gazu roboczego wynikała ze znacznego jego zawodnienia, co powodowało niewielki jego uzysk w stosunku do wydobytej wody złożowej. W zasadzie tylko dwa z odwiertów tłocząco-odbierających były w stanie uzyskać właściwą produkcję gazu. Biorąc pod uwagę aktywne zasilanie magazynu Hähnlein wodą, można uznać za oczywiste, że zastosowanie do analizy jego pracy krzywej $p / z$ nie oddaje w pełni charakteru jego pracy, który jest silnie zależny od ciśnienia i przemieszczania się wód złożowych. Skoro nie jest możliwe odebranie z magazynu ok. $G=13 \mathrm{mln} \mathrm{Nm}^{3}$ gazu $\mathrm{w}$ trakcie jego rzeczywistej eksploatacji, to najprawdopodobniej jest to związane $\mathrm{z}$ brakiem gazu w pojemności buforowej magazynu (w poduszce gazowej).

\section{Modelowanie matematyczne pracy PMG Hähnlein}

Geologiczny model podziemnego magazynu gazu Hähnlein został zbudowany w programie IHS Markit Kingdom na podstawie danych z profilowania sejsmicznego 2D wykonanego na obszarze, na którym się on znajduje. Dynamiczny model magazynu został oparty na programie Eclipse. Do modelowania dynamicznego wykorzystano następujące dane wejściowe: geologiczny model struktury geologicznej magazynującej, właściwości pertofizyczne warstwy zbiornikowej, charakterystykę PVT płynów złożowych, pierwotne dane dotyczące złoża, dane dotyczące i parametry eksploatacyjne odwiertów zlokalizowanych w obrębie magazynu, dane o ciśnieniach i strumieniu natężenia przepływu dla poszczególnych odwiertów, dane dotyczące zatłoczonych i odebranych ilości płynów złożowych.

Po skorelowaniu danych w modelu symulacyjnym dla całej historii operowania magazynem wykonano predykcję pracy magazynu. W ramach modelowania wykonano prognozy eksploatacji magazynu dla kolejnych sezonów magazynowania. Przeprowadzone symulacje miały dać odpowiedź, czy uda się osiągnąć cykliczną pojemność czynną magazynowania PMG Hähnlein na poziomie $G=70 \mathrm{mln} \mathrm{Nm}^{3}$ gazu. W matematycznym modelu operacyjnym magazynu uwzględniono też ekonomiczną stronę przedsięwzięcia oraz założono, że zatłaczanie gazu odbywać się będzie w ciągu $t=136$ dni, a jego odbiór z magazynu w ciągu $t=100$ dni.

Wyniki modelowania wskazały, że nie jest możliwe uzyskanie podczas cyklicznego operowania magazynem założonego czasu jego zatłaczania na poziomie $t=136 \mathrm{dni}$ dla przyjętej ilości magazynowanego gazu, która była pożądana z ekonomicznego punktu widzenia. Symulacja wykazała, że czas zatłaczania magazynu musiałby być znacznie dłuższy i według modelu wynosić co najmniej $t=170$ dni. Zakładany wstępnie okres zatłaczania i odbierania gazu wynosił łącznie 236 dni $(136+100)$, czyli pozostałe 129 dni przeznaczone były na przestój magazynu. Dla tak przyjętych założeń przeprowadzone 
symulacje wykazały, że w PGM Hähnlein można było zmagazynować zamiast założonych $G=70 \mathrm{mln} \mathrm{Nm}^{3}$ co najwyżej $G=57,9 \mathrm{mln} \mathrm{Nm}^{3}$ gazu.

Wiadomo, że z podziemnymi magazynami gazu typu „aquifer” (zlokalizowanych w warstwach wodonośnych) jest pewien problem eksploatacyjny. Polega on na tym, że w przypadku gdy w pracy magazynu następuje przestój przy ciśnieniu gazu w części magazynującej gaz niższym aniżeli ciśnienie w zawodnionej części magazynu, to przestrzeń porowa zajmowana jest przez napływającą wodę złożową. W takim przypadku ciśnienie w odwiertach zatłaczająco-odbierających wzrasta. Natomiast jeśli ciśnienie gazu w magazynie jest wyższe aniżeli ciśnienie wód złożowych, magazynowany gaz przemieszcza się w magazynie i migruje do bardziej odległych od odwiertów jego obszarów. W tym przypadku ciśnienie w odwiertach maleje.

Według przeprowadzonego modelowania zakładana do uzyskania w cyklach pracy magazynu ilość magazynowanego gazu na poziomie $G=70 \mathrm{mln} \mathrm{Nm}^{3}$ byłaby możliwa do osiągnięcia przy założeniu, że zostanie zminimalizowany czas, w którym w magazynie znajduje się minimalna ilość gazu. Po odebraniu z magazynu zakładanych $G=70 \mathrm{mln} \mathrm{Nm}^{3}$ należałoby niezwłocznie rozpocząć jego zatłaczanie do poziomu przynajmniej $G=20 \mathrm{mln} \mathrm{Nm}^{3}$. Wyznaczony na podstawie modelu maksymalny przestój magazynu w tym przypadku wynosi $t=10 \mathrm{dni}$, a nie, jak zakładano pierwotnie, $t=129$ dni. Symulacje wykonane na podstawie modelu wykazały również, że do minimum należałoby skrócić czas, w którym magazyn gazu znajduje się pod maksymalnym ciśnieniem roboczym, gdyż istnieje realne ryzyko przedarcia się gazu lub wód złożowych poza uszczelniającą strukturę geologiczną. To znaczy, że podniesienie ciśnienia w obiekcie magazynowym (jego dotłaczanie) powinno nastąpić najpóźniej, jak to możliwe w odniesieniu do chwili, w której ponownie rozpocznie się pobieranie gazu z magazynu (Zákopčan 2003, 2010, Wang 2009).

Zgodnie z uzyskanymi rzeczywistymi wynikami z poprzednich sezonów zatłaczania i odbierania gazu oraz reżimem czasowym eksploatacji PGM Hähnlein z zastosowaniem dopuszczalnych bezpiecznych ciśnień roboczych można zmagazynować, a następnie odebrać jedynie $G=50 \mathrm{mln} \mathrm{Nm}^{3}$ gazu. Przy takiej ilości magazynowanego gazu pojawiają się problemy z rentownością przedsięwzięcia.

\section{Podsumowanie}

Warunkiem bezpiecznej eksploatacji i działania podziemnych magazynów gazu jest prawidłowe dobranie parametrów ich eksploatacji. Ustalenie optymalnych i bezpiecznych parametrów operacyjnych jest powiązane z badaniem i monitorowaniem szczelności struktur magazynowych i jest jednym z najważniejszych czynników warunkujących działanie podziemnych magazynów gazu. 
Działania weryfikujące poprawność doboru parametrów operacyjnych dla magazynów powinny koncentrować się na szczegółowej analizie historii zatłaczania gazu do magazynu i jego odbierania (analiza zmian przebiegu krzywych $p / z$ lub zastosowanie innych metod inżynierii złożowej do oceny), a następnie - na tej podstawie - na przeprowadzeniu symulacji wartości parametrów operacyjnych z użyciem modeli matematycznych. Jest to szczególnie istotne, aby nie dochodziło do przypadków, w których przekraczane są określone krytyczne wartości ciśnień roboczych lub ilości składowanego gazu w strukturach magazynowych. Wartości ciśnień roboczych powinny być porównane z wytrzymałością uszczelnienia zbiorników w nadkładzie oraz ich bocznych częściach. Nie bez znaczenia są również wymagania ekonomiczne prowadzenia działalności związanej z magazynowaniem gazu, a te z kolei są skorelowane z ilością magazynowanego gazu. Jak wskazano w artykule, ilość magazynowanego gazu powinna być dobierana do warunków złożowych. Ilość magazynowanego gazu może mieć wpływ na jego koszty.

Czynnikiem natury geologicznej ograniczającym funkcjonowanie PMG Uhřice jest możliwość rozszczelnienia uskoku po przekroczeniu określonych maksymalnych ciśnień roboczych magazynu. Kolejnym czynnikiem limitującym bezpieczeństwo eksploatacji tego magazynu jest niebezpieczeństwo przemieszczenia konturu woda-gaz w miarę zwiększania się akumulacji magazynowanego gazu w warstwach, w wyniku czego może dojść do nieprzewidzianego przebicia uszczelnienia strukturalnego przez gaz.

Natomiast czynnikiem ograniczającym eksploatację PMG Hählein jest możliwość przesunięcia kontaktu woda-gaz po przekroczeniu wartości ciśnień powyżej poziomu maksymalnej wytrzymałości zamknięcia strukturalnego przez wody złożowe, a następnie ucieczki gazu do innej warstwy przepuszczalnej. W przypadku tego magazynu czynnikiem limitującym jest również minimalne ciśnienie złożowe magazynowanego gazu i jego ilości.

Część prac zwiąanych z przygotowaniem artykułu została wykonana $w$ ramach projektu Wsparcie Nauki i Badań Regionu Morawsko-Ślaskiego ČR (RRC/10/2019).

\section{Literatura}

Ahmed T., 2010, Reservoir Engineering Handbook, Elsevier.

Azin R., Nasiri A., Entezari J.A., 2008, Underground Gas Storage in a Partially Depleted Gas Reservoir, Oil \& Gas Science and Technology - Revue d'IFP Energies nouvelles, vol. 63, s. 691-703. http://dx.doi.org/10.2118/113588-MS.

Bujok P., Kunz A., Klempa M., Ryba J., Roček E., Křístek M., 2019, Možnosti navýšení celkové uskladňovací kapacity zemního plynu v podzemních zásobnících plynu, Uhlí Rudy Geologický průzkum, vol. 2, s. 8-12. 
Dierking H., Boor F., Schulz U., 1999, UT-Speicher Hähnlein, TDT-Messung in der BB2 am 16.6.1999, Essen.

Gas Infrastructure Europe, b.d., GIE Storage Map, https:/www.gie.eu/publications/maps/ gie-storage-map/ [dostęp: 14.07.2021].

Heymer D., Dierking H., 1993, Erdgasspeicher Hähnlein. Speichertest 1992/1993, Ruhrgas, Essen.

Horáček J., Hrdličková M., Kyselák P., Rubešová M., 2017, Podzemní zásobník plynu Stockstadt/Hähnlein. Zpráva o modelování za rok 2017, MND a.s., Hodonín.

Horáková M., 2020, Metodika výzkumu hermetičnosti PMG, Vysoká škola báňská Technická univerzita, Ostrava [praca doktorska].

Ministerstvo průmyslu a obchodu, 2019, Vnitrostátní plán České republiky v oblasti energetiky a klimatu, https://www.mpo.cz/assets/cz/energetika/strategicke-a-koncepcnidokumenty/2020/1/Vnitrostani-plan-CR-v-oblasti-energetiky-a-klimatu_final.docx [dostęp: 14.07.2021].

Rubešová M., Bujok P., Klempa M., 2017, Assessment of Integrity Wells on the Underground Gas Storage Using Measurement of Annular Casing Pressure, [w:] 17th International Multidisciplinary Scientific GeoConference: SGEM: conference proceedings: 29 June-5 July, 2017, Volume 17, STEF92 Technology Ltd., Sofia, s. 547-554.

Wang X., Economides M.J., 2009, Advanced Natural Gas Engineering, Gulf Publishing Company, Houston.

Zákopčan M., 2003, Průzkum, těžba a uskladňování kapalin a plynů - Podzemní zásobníky plynu: Postgraduální a inovační studium, Vysoká škola báňská - Technická univerzita, Ostrava.

Zákopčan M. 2010, Závěrečná zpráva matematického modelování ložiskového objektu PZP Uhřice, MND a.s., Hodonín [raport]. 